\title{
ETIKA TRANZICIONOG PRAVA
} teorije pravde Aristotela, Rolsa, Nozika, Maršala i Radbruha. Te je i ovaj rad inspirisan njihovim naučnim doprinosima. Dakle, tranziciono pravo i njegova defektna pravičnost rezultat su loših unutrašnjih i spoljnih okolnosti, unutrašnjih okolnosti nasleđa socijalističkog autoritarnog prava, i spoljašnjih procesa globalizacije čiji cilj nije bilo stvaranje pravičnog nego zavisnog društva. Unutrašnja moralna hromost društva podstaknuta nepovoljnim nasleđem prethodne države i prava, i sama je upala u moralni nihilizam i normativni relativizam te stoga nije mogla da izgradi pravo kao činilac razvoja uz uvažavanje socijalnih prava. Socijalna prava ljudi potčinjena su posesivnom amoralizmu globalnog liberalizma tržišta. Ako bi smo pored etike, pozvali u pomoć, antropologiju i psihologiju onda bi rekli da naš mentalitet nema osećaj za pravdu, nema svest o značaju prava i pravde kao ljudskog dostojanstva.

Ključne reči: etika, tranzicija, pravo, pravda

\section{Uvod}

T ranzicija je period prelaza iz jednog društvenog sistema u drugi, iz jednog prava u drugo. S'toga ako je pravo deo društva odnosno regulativni sistem društva, onda je i pravna tranzicija deo ukupnog tranzicionog procesa konsolidovanja pravne države i vladavine prava. U Uvod u pravo, prof. Mitrović ${ }^{1}$ je napisao da je pored ostalih, tranzicija jedan od oblika državnopravnog poretka. Iz tog čitanja shvatam da nije dovoljno samo ustanoviti puko pravo kao volju transmisione ${ }^{2}$ tranzicione elite. Ako nije bilo dovoljno „socijalizma sa ljudskim likom" možda je sada došlo vreme da tako formatirani posesivni, sebični kapitalizam bude više oljuđujući sa „humanim, ljudskim likom“.

U procesu transformacije društva, pravo (što više pravično ciljano) ima strategijski značaj jer normirana stvarnost koju treba uspostaviti ima funkciju pozitiviranja novog tipa društvenih odnosa. Ne samo pravo već i drugi normativni sistemi društva, a pre svega

\footnotetext{
${ }^{1}$ Lukić Košutić Mitrović. Uvod u pravo. Beograd, 2001.

${ }^{2}$ Iskustvo je odista isuviše jasno, da glavni akteri tranzicije su samo recipijenti i tranmiteri prava zapadne civilizacije koje je i samo ostarelo u svom iskustvu...
} 
moral, imaju istu funkciju: stvaranje novog društva koje je drugačije od prethodnog, stvaranje novog prava u odnosu na prethodno, stvaranje i usvajanje novog normativnog obrasca društvenog ponašanja zasnovanog na etičkom sadržaju tranzicionog prava.

Političke i državne zajednice obeležene su protivrečnošću između društvene realnosti represivne državne vlasti, s jedne strane, i potrebe za opravdanjem te represije, s druge strane. ${ }^{3}$ Sva moderna društva u potrazi su za nekom vrstom racionalne ravnoteže između fakticiteta (oficijelna, pretnjom monopolisane prinude garantovana suprematija državno-pravnog aparata) i moralne validnosti (razlozi kojima vlast utemeljuje zahtev za poslušnošću podanika). Moderni politički režimi razlikuju se po tipu moralnog razloga kojima opravdavaju prinudu, i po statusu podanika koji je definisan ovim razlozima. Institucionalno-pravna arhitektura režima uvek se ispostavlja kao izvod ovog temeljnog legitimacijskog obrasca.

Opravdanje odnosno legitimnost tranzicione državne vlasti je u osnovi moralnog karaktera i izražava se u obrazloženju nove legitimnosti pomoću moralnog opšteg dobra zbog koga je zajednica i ustanovljena. Moralno utemeljen projekat društva i autoritet nosilaca javnih funkcija u tranziciji zasnivaju se na pretpostavci o komparativnoj prednosti novog državno-pravnog poretka u odnosu na prethodni. To znači da nova formacija države i prava treba bolje da izrazi opšti društveni interes kao „dobro zajednice“ u odnosu na prethodni.

Dakle, novoustanovljena vlast represivne države mora biti moralno opravdana i utemeljena na dobrim argumentima etičnosti kao opšta potreba regulacije ukupnih društvenih odnosa, a proces opravdanja legitimne upotrebe sila mora se zasnivati na cilju koji se ostvaruje.

Univerzalno zadati sistem osnovnih prava, demokratske politike i pravno ograničene državne moći nisu uvek moralna replika principa na kojima se zasnivaju. Moralne vrednosti, jednakost i sloboda, čovekovo dostojanstvo, autonomija i pravda, manje ili više se opredmećuju kroz formu ideološkog i pravnog poretka. Na normativnom nivou, demokratska vladavina prava opravdava se načelom da sloboda ljudi koji jedni druge priznaju za moralno jednake zahteva posebne mehanizme institucionalne zaštite i društvene podrške. Demokratija štiti ljudsko dostojanstvo koje onemogućava svakog čoveka ponaosob i sve ljude zajedno da budu u potpunosti i neposredovano autonomni.

Ali proces moralizacije prava u tranziciji ne ide bez otpora i uticaja nasleđa. Nasleđe ima svoje protezanje i na tranziciono pravo. Dve su konstante karakteristične i za prethodni i dolazeće tranzicione režime. Prvi je da je pravo instrument političke moći, odnosno da je umesto vladavine prava ustanovljen sistem „vladavine pomoću prava“. Vladavinska volja je pretočena u pravnu zapovest kao selektivno heteronomna volja inspirisana parcijalno grupnim interesom. Instrumentalna zloupotreba prava je osnovni sadržaj ovog principa. Druga konstanta odnosi se na izmeštanje političke volje izvan moralnih i pravnih okvira. Razumevanje i praktikovanje vlasti od strane političkih elita svodi se na moralno i pravno nedopuštenu neograničenu vladavinu u ime konstruisane ili fiktivne većine. „Autoritarna partijska anestezija prava protegla se u postkomunistički i tranzicioni period i stvorila izrazito zavisno pravo, a naročito pravosudni sistem, u odnosu na izvršnu i zakonodavnu vlast. Prevalencija partijske i finansijske moći u odnosu na pravo, etike nad parcijalnom voljom transverisanom u pravnu normu, je suštinska značajka trancizio-

\footnotetext{
${ }^{3}$ Jürgen Habermas, Faktizität und Geltung. Beiträge zur Diskurstheorie des Rechts und des demokratischen Rechtsstaates (Frankfurt am Main: Suhrkamp, 1992), str. 43-47.
} 
nog prava. Funkcionisanje pravnog sistema nije podrazumevana, sama po sebi, automatizovana primena prava, već je uvek potreban neki spoljašnji heteronomni faktor koji više osujećuje nego ohrabruje pravične pravne procedure". 4

Stoga, pravo u tranziciji više ima instrumentalnu, funkcionalnu, parcijalnu funkciju legalizovanog interesa krupnog kapitala, finansijskih lobija, i interesa međunarodne politike. Cilj tranzicionog prava nije pravičnost, nego s jedne strane regulisanje ponašanja aktera u interesu manjine, a s druge strane, i ono samo generiše nepravdu i stvara osnove za legalizovanu nejednakost.

Polazeći od Radbruhovog ${ }^{5}$ razvrstavanja „zakonskog neprava“ i „nadzakonskog prava" odnosno pravde, moguće je istražiti i utvrditi koliko je svako društvo pravedno u pozitivno-pravnom smislu i u van pravne normativnosti. Nadzakonska pravda je rezervni potencijal društva da koriguje stepen pravičnosti ne samo zakonskog prava nego i društva koje je predmet pravne regulacije. Zakonska pravda ne služi dobru pojedinaca, zajednica i kolektiviteta, ako je zakon instrument koji nameće autoritarnu volju posebnih moćnih grupnih interesnih struktura. Ako je osnovni diskurs zakonske pravde politička moć onda je moralnost prava dovedena u pitanje, jer ona ne služi dobru pojedinaca, grupa i društva u celini. Takvo pravo nema etički karakter nezavisne i slobodne institucije jer je u osnovnoj prirodi autoritarno. Kolonizovano i autoritarnom heteronomnošću stvoreno, ono ne može služiti dobru zajednice.

Korektiv zakonske nepravde nalazi se u repertoaru pretpostavki, vrednosti, i normi nadzakonskog prava. Nije svako pravo pravedno, ono je manje ili više, i repertoar korektivnosti pozitivnog prava i nalazi se van represivne norme važećeg prava. Etičnost odnosno pravednost tranzicionog prava ostala je defektna, zbog nasrtaja unutrašnje i međunarodne moći. Ekonomska invazija stranog finansijskog kapitala u već uveden kapitalistički sistem tranzicionih društva dovela je u ovim društvima do „kapitalizma katastrofe“ u kome su preduzetnička prava značajnija i prioritetnija od socialnoekonomskih prava radnika, čime se narušava ravnoteža pravičnosti između vlasnika kapitala i radne snage, stvorena bazična nejednakost u sticanju dobara za egzistencijalni život, stavlja radnika u položaj obrazovanog i kulturnog roba za sticanje profita. U startu, na nivou državne politike i ustavnog okvira, stvorena je nepravična početna pozicija za stvaranje zakonske nepravde, a koncept autoritarnog legalizma je stvorio dobro pravnonormativno tlo. Izrazita nejednakost na relaciji kapital - rad stvorila je siromaštvo, još veće raslojavanje stanovništava i rub egzistencijalne bede. Čini se da nadzakonsko pravo više lebdi i potisnuto je pod diktatom moći i novca, a da pozitivno pravo sve više ogreza u nepravičnosti.

\section{Rolsova teorija u uslovima tranzicije}

Dva principa pravde: sloboda i jednakost predmet su Rolsovih istraživanja u delu Teorija pravde. Naime Rols polazi od dva principa pravde koji nam omogućavaju analizu i razumevanje tranzicionog prava. Prvi princip govori da svaka osoba ima slobodu jednakih mogućnosti, slobode koje su spojive sa sličnim šemama slobode za druge. Drugi

\footnotetext{
${ }^{4}$ Kovačević, S. Tranzicija u demokratiju - transformacija društva i konsolidovanje demokratije, Niš, 2015.

${ }^{5}$ Radbruh, G, Filozofija prava, Pravni fakultet u Beogradu, 2016.
} 
princip pravde koji Rols uvodi je da društvene i ekonomske jednakosti treba da budu uređene da je istovremeno: (a) razumno je očekivati da budu svakom od koristi, (b) da su povezane sa položajima i službama jednake za sve. ${ }^{6}$ Iz ovoga se mogu, na primeru tranzicionih zemalja izvesti neke konkluzije (1) od zahteva za jednakošću stvorili su se ogromni socijalni raskoli, raslojavanja i siromaštvo, princip jednakosti dobio je dimenziju bazične nejednakosti stvorene interesnom invazijom ekonomske i političke klase; 2) jednake mogućnosti za sve invertovale su se u stanovitu principijelno praktičnu inverziju da su samo neki jednaki i jednakiji, a da su svi drugi u startnoj nejednakoj poziciji, odnosno bez mrve mogućnosti da se socijalno ekonomske jednakosti ublaže a kamo li ujednače; „početna pozicija“ je ekstremno nejednaka i nije ista za sve, „prvobitni ugovor“ se pretočio u „poligički dogovor" otuđenih elita (3) moralno dostupna dobra i položaji filterom „partijske podobnosti“ su se preobrazila u stanje apsolutne odnosno veoma selektivne pristupnosti javnim dobrima, položajima, zaposlenju; korisni su samo nekima a velikoj većini uskraćeni uz eventualnu mogućnost obligacije: ti meni podršku na izborima ja tebi pristup nekom materijalno malom dobru ili zaposlenju.

Zašto bi okolnosti ili posledice koje nisu čovekova zasluga uticale na srozavanje njegovog građanskog etosa i egzistencijalne sigurnosti i nejednaku, nehumanu i nepravičnu distribucija materijalnih dobara, uloga, položaja i statusa. Od rolsovog zahteva da se princip razlike mora uključiti u distribuciju pravde, ostalo je da je različitost štetna i destabilizujuća.

Favorizovanje principa (tržišne) slobode na štetu jednakosti (socijalne) izaziva destruktivne posledice. Nozikova minimalna država favorizuje slobodno tržište, ali samo tržište strukturno favorizuje jedne interese na štetu drugih, država neće biti neutralna iako to Nozik uvek pretpostavlja; neutralnost države dovodi ne samo do nebrige za zajedničko i opšte dobro, nego se udaljava od društva, prepuštajući da tržište odnosno novac bude jedni, Bogomdani (de)regulator odnosa.

Veza između privatnog i javnog dobra se rastače i invertuje. Privatni interes se nameće i promoviše kao interes celog društva iako je on parcijalan i odnosi se na interese manjine. Parcijalno dobro se predstavlja kao dobro svih zajednica a ono što stvarno treba da bude javno dobro uveliko se privatizuje. Otuda poznata sintagma iz tranzicione retorike - privatizovana država.

Ako su prava društveno i istorijski ustanovljena onda su prava koja brani Nozik kao prirodna i prvenstvena, pre svega, prava tržišta, onda su ona i ranije a posebno u tranzicionom periodu, definisana, politički podržana i konstituisana, dakle definisana od strane i unutar okrilja kapitalističkih posedničkih veza. U prelaznim društvima današnjice pravna obligacija (koja ima i politički legitimitet) je uspostavljena između posedničke klase novca i kapitala i političke klase na vlasti: prvima treba pogodan politički ambijent, a drugima treba, referenca ekonomskog razvoja, referenca koja je u tranziciji skrenula ka ekonomskom bogaćenju manjine unutar vlasti društva.

Ima li nade epohalnog sporazuma, približavanja, konvergencije, liberalizma i slobode? Da li je u novim demokratijama i tranzicionim pravnim sistemima potrebno više ljudskog humanog lika? Da li liberalni kapitalizam može iskoračiti ka liberalnom socijalizmu ili socijalnom liberalizmu? Da li je i koliko moguća korekcija kapitalističkog liberalnog mode-

\footnotetext{
${ }^{6}$ Rols, Teorija prave, Beograd, Podgorica, 1998.
} 
la sa socijalnim pravima i slobodama ljudi? Ili je samo prvotni surovi kapitalizam nužna „dolina suza“ (Darendorf) jedna faza ka oljuđivanju i čovekovoj svrsi. Ako jeste, koliko traje ta faza, jer ako pogledamo trodecenijsko iskustvo ovih zemalja teško je utvrditi da je to samo faza već relativno trajan proces. Pitanja su koliko retorička toliko i indikativna, koliko suštinska toliko i praktična. Praksa traži dobar život građana u suštini. A da li je to moguće u uslovima nejednake distribucije moći i primata finansijskog kapitala.

\section{Država i pravo u tranziciji i potreba reformističke redefinicije}

Maršal $^{7}$ i Rols odbacuju tradicionalnu doktrinu dominacije tržišta a akcenat stavljaju na jednakost kao suplement, korektiv tržišnim slobodama bez granica. To je veliko postignuće da su i zapadne zemlje poklekle pred izazovom nejednakosti i tadašnje pretnje globalnog socialkomunizma. Njihov reformizam koji je značio pokušaj konvergiranja slobode i jednakosti značio je ustanovljavanje kompromisa, približavanja, komprehenzije, osmoze i kritičke kompilacije liberalizma i socijalizma, individualizma i komunitarizma odnosno kolektivizma. Tako je došlo do obavezivanja reprezentativne demokratije da usaglasi slobodu i jednakost. Krajnosti teškog i ekstremnog kolektivizma i ekstrapoliranog tržišnog liberalizma se uviđa kao potreba prevazilaženja apstraktnog i manipulisanog opšteg dobra ili opšteg interesa ali i posesivnog, gramzivog, koristoljubivog dogmatskog tržišnog liberalizma. Državna intervencija je trebala da reguliše tržište ukoliko ono preti da ugrozi i dezintegriše društveni život koje razdiru nejednakosti, da spreči atomizaciju, otuđenje i raslojavanje.

Tomas Grin je bio individualista i usvojio ličnu slobodu ali slobodu u opštem smislu a ne samo u tržišnom. ${ }^{8}$ On je svoj liberalni individualizam revidirao jer je smatrao da osvojena prava nisu opoziva i jednostrano shvaćena, naglašavajući da su pojedinci društvena bića a svoje sposobnosti su stekli onda kad su integrisani u širu zajednica i time postali povezani sa širim društvenim dobrom. Biti slobodna, razumna i moralna osoba znači živeti sa opštim dobrom koje obezbeđuje i dobro pojedinca.

Maršal je idejno, naučno i doktrinarno najzaslužniji za koncipiranje korpusa socijalnih i ekonomskih prava odnosno socijalne pravde korektiva destruktivno razarajućih efekata tržišta koja produkuju nejednakosti. Dok je s druge strane, Klaus Ofe zaključio da su sve tranzicione zemlje i njihovi pravni i politički sistemi zapostavili dalekosežnu socijalno-ekonomsku komponentu prava i sloboda. Uostalom Pakt o socijalnim i ekonomskim pravima, ratifikovan od strane država, treba da bude osnov koncepta dostojanstvenog građanstva koje treba da ima jednake mogućnosti i prava na slobodu ali i sigurnost od rizika prirode i tržištem uslovljenog raslojavanja i siromašenja društva.

Evoluciju klasičnog liberalizma ka socijalnim interesima pojedinca i grupa, oživotvorenje socijalnog liberalizma možemo rekonstruisati u naučnim društvima u kojima je kapitalizam pokazivao i pokazuje loše strane. Takođe, i urušavanje social komunizma zbog političke represije i ekonomskog sunovrata je doživljeno u ovom prethodnom režimu. Zar to nisu dva značajna iskustva koja smo mogli da spoznamo, programiramo i variramo u no-

\footnotetext{
${ }^{7}$ Marshall, T. N. Class, Sitizenship and Social Development, Greenwood, Westport, 1973

${ }^{8}$ Greengarten, Tomas Hill Green and the Development of Liberal Democratic Thought, Toronto Univ. Press, 1981.
} 
vom kontekstu države. Nismo znali da selektujemo onu dobru tradiciju iz oba rivalska svetska sistema i učeći na njihovim greškama stvorimo pravičniju zajednicu tranzicije. I ne samo to, da spoznamo dobre i loše strane zapadnog konstitucionalizma, (vladavinu prava i pravnu državu) da ih usvojimo i učinimo još pravednijim: da stvorimo pravednu državu i humanistički moral društva.

\section{Pravičnost tranzicionog prava ili pravičn(ij)a država}

Etička delovanja i postignuća društvenih, ekonomskih i političkih elita u tranziciji utvrđujemo preko dve teze: prva je koliko su akteri tranzicije uključujući i pravne institucije demokratizovali svoju propisanu i očekivanu ulogu, pa odmah treba reći da je „nemoralnost u politici i nemoralna politika“ (Čupić) dovela do slabe etičnosti prava i lošeg fukcionisanja ukupnih institucija. Odmah se može reći da su korupcija i nedelotvornost institucija osnovna karakteristika ukupnog prelaznog razdoblja. Etničko je nadvladalo etičko, normalno je ustupilo mesto devijantnom i patološkom, moralni apsolutizam je postao moralni relativizam ili moralni nihilizam, pravni normativizam se preobrazio u pravni voluntarizam (tehnički preveden u pravnu normu), Ustavom proklamovana prava i slobode su operacionalizovana u odgovarajuće zakone, pretvorila se u anemično i poluanarhično društvo, „imati pravo“ pretvorilo se u dobijanje tog prava preko veze ili pomoću interesnog nepotizma, a dezorijentisana i difuzna sloboda postala je oktroisana i upravljana, vezanost za vođu je potisnulo vezivanje za vladavinu prava i zakon.

I socijalistički moral i socijalističko pravo i na njima izvedena pravičnost imala je bela bezsadržinska polja: „država je bila dadilja koja hrani i brani“ (Gidens), a socijalna politika i socijalna pravda prekoračili su granicu svoje smislenosti i stvorili infatilnog, zavisnog građanina. Socijalna politika i socijalna pravda sve više su postajali ustanove za socijalno zbrinjavanje radno sposobnih ljudi. Etika radnog prava je toliko degradirana da se iskovala cinična replika: „ne mogu oni mene toliko malo da plate koliko ja mogu malo da radim“. Etika rada je ustuknula pred neradom, pasivizmom i anarhičnim shvatanjem rada a imperativ racionalnog privređivanja pretvorio se u političko rasipništvo ogromnih socijalnih fondova.

Pa kako je onda raspoređena pravda u tranzicionom pravu i društvu? Da ne počinjemo sa večno važećim aristotelovim tipovima pravde ${ }^{9}$, ovde ćemo samo pokazati kako su pojedini modeli pravde (distributivna, komunitativna, socijalna odnosno solidarna pravda) raspoređeni kroz zakonodavstvo i kroz pravnu praksu. Pravičnost tranzicionog prava razaznajemo preko tri modela pravde, distributivne, komunitarne, solidarne ili socijalne.

Komunitarna ili korektivna pravda podrazumeva vladavinu prava, poštovanje ustava i zakona koji su u skladu sa opštim dobrom, opštim i javnim interesom i takođe zahtev da se sa građanima postupa jednako. Primenjen na tranziciono pravo, može se konkludentno tvrditi da zakoni nisu uvek u sklad opštim dobrom već su često rezultat selektivno grupne volje i interesa koji se nastoji prikazati (racionalizovati) kao opšti javni interes. Dobro društva je ono što vlast kaže. Zakon je ono što je u interesu vladajuće grupe i više izražava posesivne interese gramzivih društvenih koterija. Imperativ jednakog postupanja prema građanima narušen je i samim ustavnim i pravnim normama, a o faktičkom postu-

\footnotetext{
${ }^{9}$ Aristotel, Nikomahova Etika, IK Zorana Stojanovića, 2013.
} 
panju prema građanima možemo reći da se građani više vide kao podanici, izvršioci, koji imaju samo obaveza prema državi a koliko će prava imati to će im država odrediti u skladu sa svojom politikom. Često se političari opravdavaju da ostvarivanje prava u mnogome zavisi od materijalnih i drugih uslova koji se još nisu stekli a da je njihova tobož dužnost da stvore takve uslove građanima. Ne crkni magarče do zelene trave!

Distributivna ili raspodelna pravda postoji u odnosima pojedinca i zajednice i između samih pojedinaca međusobno, u učešću građana u sumi dobara ne samo materijalnih već i duhovnih srazmerno svojim doprinosima i učincima u društvu. Faktičko funkcionisanje ove vrste pravde govori nam da građani ne učestvuju srazmerno u količini opštih dobara društva (to pravo je privatizovano i ekskluzivno). Sto se tiče doprinosa društvu, velim da se dobija nezasluženo a da se zasluženo ne vrednuje ili jedva vrednuje. Što se tiče sticanja materijalnih dobara i vrednosti, taj proces je protivzakonit, burazerski, netransparentan. Antivrednost i kvaziproizvod se precenjuje, a prave vrednosti i pošteni rad podcenjuju. Da rad nije vrednovan pokazuje i to što se nerad nagrađuje, a rad nipodaštava i obezvrednjuje. Od nerada se komotno može živeti, a od rada se jedva preživljava. Bolesno društvo ignoriše one koji doprinose, one koji su talenti, koji su nosioci razvoja i progresa, čija delotvornost je univerzalno priznata. Takođe defektno društvo nagrađuje one koji ne privređuju, koji ne uče, koji sve postižu „preko veze“, koji su kriminalizovani i korumpirani, koji više odmažu nego što pomažu, čiji „rad“ je čist gubitak. Gubitnici se nagrađuju a dobitnici se kažnjavaju.

A šta je sa solidarnom pravdom? To je ona pravda koja se brine o onima koji nemaju, ne svojom voljom, već voljom tržišta, objektivnim okolnostima življenja, oni su gubitnici promena, oni koji nemaju posao. Tranziciono defektno društvo nema sluha ili osećaja pravde za takve. Oni su na marginama društva i ličnoj patnji. Bez obzira što naš ustavni i pravni sistem promoviše i propisuje pravno i pravedno postupanje, problem nastaje u samom procesu primene prava, primene prava koja je često selektivno primenjena. Bez obzira što i sam nije sposoban da obuhvati svu složenost „raspadajućih egzistencija čoveka“, tranzicioni sistem nije izgradio moralne standarde solidarnosti, emaptičnosti, osećaja za pomoć drugom kad je u egzistencijalnoj nevolji.

Bilo koji od postojećih oblika pravde u tranzicionim zemljama je pretežno zakazao. Stoga se može ustvrditi da je tranziciono pojmljeno i praktikovano "pravo“ ostavilo jedan veliki populacioni prostor da živi u uslovima ohole nepravde.

\section{Društveni koreni (ne)pravde u tranziciji}

Stanje građanske vrline u tranzicionom procesu, sa nasleđem autoritarnog nacionalizma i patrimonijalnog unopartokratskog etatizma, ne usvaja se i ne primenjuje lako. Ali „građanska vrlina“ je legitimna samo ako služi interesima kapitala i moći vlastodržaca. Pored ovih, mnogi ukršteni razlozi i motivi demotivišu konstituisanje moralnog, pravičnog društva kome je opšte dobro i opšta korist svih, osnovni etički izazov. Moralni i pravični mentalitet društva se gubi u uslovima nesigurnosti i neizvesnosti. Takvo stanje stvara strah, posesivnu ličnost, svest o svome ,ja“. Briga o sebi učinila je da nikog nije briga za drugoga. Sloboda i jednakost jesu osnovne matrice pravde ali da ne zaboravimo i bratstvo kao treći univerzalni ideal pravičnosti postupanja prema drugom. Na tranzicionom 
putu, bratstvo među ljudima se izgubilo, isplivao je individualni interes koji je pogrešno pojmljen kroz repliku: ,ja moram da preživim a za druge me nije briga“. Bez bratskog morala kidaju se neophodne veze ljudi u društvu, kida se nešto što je vezivno tkivo svakog društva a to je emocionalni odnos kao bazični početni stav u odnosu sa drugim ljudima.

Kad učimo od drugih, posebno bolje organizovanijih, uspešnijih i bogatijih društava, mi smo uvek pasivni i nekritički receptori umesto da smo kritički i prilagodljivi perceptori koji uče na dobrim iskustvima drugih. Nije nam to ni prvi put da učimo na lošim i prevaziđenim iskustvima drugih. Uvek kaskamo i bavimo se davno prevaziđenim. Nismo kadri shvatiti šta je dobro a šta nije u inplantaciji tuđeg iskustva kad već nismo sposobni da stvorimo svoj racionalan, delatan, ljudski, autentičan sistem društvene etike. Kako se odnosimo prema sebi tako se i drugi odnose prema nama. Ovaj topos nam pomaže da vidimo kakve kako nas drugi gledaju i šta od nas očekuju, šta misle i šta im je cilj.

Nekritičko instaliranje liberalne posesivne etike, instrumentalizacija i zloupotreba ljudskih prava i sloboda doveli su do stanja ideološke impostacije ljudskih prava. Imajući u vidu globalni proces promocije i instalacije liberalne demokratije u Istočnu Evropu, može se iskoristiti poznata sintagma „imperija i ljudska prava“ (Duzinas) a dosadašnji bilans preuzimanja ekonomskog modela života možemo odrediti kao „kapitalizam katastrofe“.

Sve ovo nam kazuje na imperijalnu funkciju impostacije ljudskih prava ali samo selektivnih ljudskih prava kojima je suženo značenje. To je onaj interesno postavljen liberalizam sa otvorenim društvom, kako bi imperijalni zahtevi za kontrolom resursa i dobara, nesmetano investirali kapital uz nedopustivo najpovoljnije uslove ne u cilju razvoja Srbije nego u cilju zgrtanja profita. Ako instalirana demokratija ne služi interesu globalizovanog kapitalizma katastrofe, onda ta država neće imati podršku i neće se smatrati liberalnom i demokratskom. Ljudska prava i slobode su postale funkcije imperijalne moći i geostrateških interesa moćnih država i svetskih organizacija.

Neoliberalno pravo u tranziciji produkuje takvu etiku radnog položaja radnika u kome se fleksibilizuje tržište, smanjuje ili urušava uloga sindikata i sindikalnog pravnog organizovanja, glorifikuju strane investicije i interesne simbioze vlasti i investitora, klijentelizam uzdiže predstavničku demokratiju, bez moralnih i socijalno-pravnih granica i obzira prema siromašnom društvu.

Bez društva pravednika nema ni državne, političke, socijalne i individualne pravde. Bez društvenog osećaja pravde, nema ni unutrašnjeg nerva u državi da stvori pravedno pravo. lako su prelazna društva krizna, u kome se smenjuje tradicionalni i nastupa novi moral, nijedna politika promene ne može biti imuna od pravde, i ne može zaobilaziti čoveka kao osnovnu vrednost društva koje se transformiše.

\section{Zaključak}

Etika zakona ne može da reši moralne ambivalencije društva i ono što politička volja nameće. Etički paradoks pravnih poredaka tranzicionih zemalja i jeste u tome što pravna norma nema etički sadržaj a priroda svake norme je njena etička celishodnost. Moralni kapacitet društva je osnova uspešnih promena na bolje i zdravije društvo. Ako moralni sadržaj ukupnih društvenih odnosa nije saglasan sa moralnim delovanjem njihovih aktera, onda ni ishodi takvog procesa neće dovesti do etičkog dostojanstva društva koje se 
gradi. Ako je moralno i pošteno delovanje izašlo iz mode, nikakva modernizacija neće imati uspeha. Ako akteri i nosioci politike tranzicije koriste nemoralna sredstva u ostvarivanju tog cilja onda se postavlja pitanje da li je etično "gaziti leševe“ do plemenitog cilja. Ako pravo i moral društva nisu u saglasnosti onda je i pravo lišeno moralnosti. Ako se politika odavno razvela od morala, to ne znači da je i pravo posrnulo i postalo etički defektno. Ako pravno ne sadrži maksimum pravičnosti, onda je i pravo nepravedno. Ako pravo nije stvoreno kao pravični regulativni sistem društva, onda će isto to pravo stvarati nemoralne iskustvene prakse. Ako nema moralnih i kulturnih standarda življenja, ako pravo nije pravični sudija društvenih odnosa, onda se naša egzistencija svela na puku instrumentalnost preživljavanja, a onda je i zlo pobedilo dobro. A kada dobro ustukne pred zlovoljom, onda nema više razvoja ni društva ni čoveka.

Sunovrat u zajednicu vraća nas u pretpolitičko i predgrađansko stanje a zahtev za moralnim obzirom prava i društva vraća nas na etičko u čoveku i kazuje nam da ljudska priroda nije baš dobra i da je treba popraviti i oljuđivati. Etički zaborav nas navodi na pomisao vraćanju moralnoj normi. Ako norma nije nešto što čovek nosi u sebi kao putokaz u spoljašnjem tranzicionom kolopletu okolnosti onda se moralno neće podudarati sa društvenim ja. Etika pravne norme predstavlja svesni oblik iskustava i racionalno pravilo koje se orijentiše na iracionalne nemoralne sile u nama. Moralni a i pravni život nastaje kad se rađa humanistička svest koja je svesna razlike dobra i zla. Jer ostvarivanje najvećih vrhunskih humanističkih vrednosti pretočenih u pravnu normu treba da bude najdublji smisao etike tranzicionog prava.

\section{Literatura}

[1] Aristotel, Nikomahova Etika, IK Zorana Stojanovića, 2013.

[2] Rols, Teorija pravde, Beograd-Podgorica, 1998.

[3] Nozik, Robert, Država, anarhija, utopija, CID Podgorica, 2010.

[4] Marshall, T. N. Class, Sitizenship and Social Development, Greenwood, Westport, 1973.

[5] Kovačević, S, Tranzicija u demokratiju, Pravni fakultet, Niš, 2015.

[6] Jürgen Habermas, Faktizität und Geltung. Beiträge zur Diskurstheorie des Rechts und des demokratischen Rechtsstaates, Frankfurt am Main: Suhrkamp, 1992.

[7] Lukić Košutić Mitrović, Uvod u pravo, Beograd, 2001.

[8] Radbruh, G, Filozofija prava, Pravni fakultet, Beogradu, 2016.

[9] Greengarten, Tomas Hill Green and the Development of Liberal Democratic Thought, Toronto Univ. Press, 1981. 